\title{
Learning Culture in Madrasah School
}

\author{
Wibi Wijaya ${ }^{1} \quad$ Shafwan Mahmudin $^{1} \quad$ Umar Dani $^{1} \quad$ Fahmi $^{1} \quad$ Arina Ida Putri ${ }^{1}$ \\ Rusdinal $^{2} \quad$ Firman $^{2}$ \\ 1.College student at Program Study Postgraduate Knowledge Sciences Education Social Padang State University \\ 2.Postgraduate Lecturer at Padang State University
}

\begin{abstract}
This study aims to analyze the learning culture of students in madrasah schools. This research is a qualitative study with a type of case study. The unit of analysis of this study is MAN 2 Padang. The subjects of this study consisted of Principals, Teachers, Students, and Educational Personnel. Data was collected by interview, observation and documentation techniques. Data analysis uses an interactive analysis model that includes three stages, namely (1) reduction (2) presentation (3) verification / conclusion drawing. The results of the study showed that the learning culture in madrasah schools identified in MAN 2 Padang included three findings. First, namely the stage of student learning activities. At the stage of student learning activities are carried out in a variety of ways, one with individuals / individuals, pairs, making small groups, or in classical forms. Second, a conducive and calm learning atmosphere, in this situation the benchmark is a calm and comfortable learning atmosphere, namely creating learning activities 1). Relax, but still serious 2). Fun (there is active communication between teacher and student), 3). Educate and educate, and finally 4). Give reinforcement to students. Third, the benefits of the existing learning culture and schools in MAN 2 Padang, namely cultivating a good attitude and then informing all existing school members about the form of behavior that must be carried out in the school environment of MAN 2 Padang in order to shape students' personalities and character in the school area in accordance with the vision, mission, culture, values, norms that can be implemented in the school area both internal and external.
\end{abstract}

Keywords: culture, study, madrasah school.

DOI: $10.7176 / \mathrm{JCSD} / 45-04$

\section{Introduction}

In essence learning is the entire learning process both in the form of interactions and situation conditions that exist in the environment around individual students. Learning can be seen as a process of cultivating values directed at achieving the goals and processes of doing through an experience created by the teacher. The quality of learning is very dependent on planning from the start, including the implementation, and evaluation carried out by the teacher itself. The task of a teacher is not just teaching (teacher centered), but rather to teach students (children centered). The learning activities carried out through two actors, namely teachers and students. The teacher conducts learning to shape student behavior through the learning process. While the learning process carried out by the teacher is related to the creation of conditions of learning that are oriented towards the needs and demands of the quality of current learning (Rusman, 2017: 75).

Learning culture is all activities carried out by students in carrying out their learning tasks so that it can become a habit. The success of learning in education is determined by the habits carried out by students. All forms of positive learning habits in each process that is passed must continue to be developed for the future. This learning culture has a very close relationship with student learning achievement. Because, in learning culture contains the meaning, meaning and certain ways adopted by each individual student. For that a good learning culture will create good learning achievements.

In accordance with the previous discussion, that learning culture can create changes in behavior that are relative in students. From the definition includes three elements, namely (1) learning is a change in behavior, (2) practice and experience is one aspect of the change in behavior, and (3) changes that occur are permanent, and remain in a sufficient time period long time ago (Aunurrahman, 2011: 48).

In school there are factors that greatly influence the process of learning culture that is passed by students. These factors include internal and external factors. Internal factors are factors that exist in the individual students who are learning, while external factors are factors that are outside the student's self. In internal factors there are three influencing factors, namely fatigue, psychological and physical factors (Slameto, 2003: 54). Factor of fatigue is a factor causing disruption of the learning process, for example, lack of enthusiasm, often experiencing dizziness and disability and poor health conditions. Furthermore, psychological factors can also influence student learning culture such as intelligence, interests, talents, attention to levels of fatigue (level of lethargy and boredom), and the last, namely physical factors, namely a condition of good and bad health of individuals.

According to Koentjaraningrat (1990: 147) cultural factors are closely related to habits, customs, perceptions, perspectives and cultures of different peoples. Because each individual is good, students always experience contact and interaction with the community, therefore cultural influences that are negative from the 
community in this case the world of education will greatly affect the development of children (students). Students who play and hang out with friends who do not like to learn may go along with not liking learning, and vice versa. In accordance with the opinion (Slameto, 2003: 73) "many students experience failure in learning because they do not have a good learning culture, most of them can only memorize.

In accordance with what has been explained previously also, that the learning culture of students has a correlation with student achievement, because in it contains the ways and techniques adopted by students. In general, every human being (person / student) will act based on the force of habit (according to his habits) even though the student knows there is a way that is more beneficial for him. According to Rousseau that every human being has a good soul, he experiences changes to be bad or evil because of the influence outside of themselves namely culture. However, a more complex problem will arise if society experiences cultural backwardness (Dalyono, 2001: 106).

Thus, it can be explained that a good learning culture includes a provision, skills and accuracy in completing tasks, and eliminates everything that can have a bad impact on the learning process so that it can affect good learning achievement. In addition there is a personality that becomes a benchmark in clarity of thought. Clarity of thinking in the learning process (learning culture) and learning must be maintained. Likewise with the opposite, if the student's learning culture is not good then it will make the student become acting as he wishes, becoming a lazy and irregular person in learning.

According to the behavioristic theory of learning is an expected change in behavior due to the interaction and the giving of a stimulus and response. In other words, learning is a form of change experienced by a student in terms of his ability to show new behavior as a result of interactions in giving stimulus and response earlier. For example, a student has not been able to behave politely even though the teacher has taught it, but in reality he has not been able to behave with manners so that the student is considered not yet learning. So from that the most important thing in this case is an input (Budiningsih, 2005: 20).

\section{Research Methods}

This research is a qualitative research with a type of case study in analyzing how the learning culture of students in this madrasah school. The subjects of this study were all MAN 2 Padang school residents. This school was chosen because it included superior Madrasah schools with A accreditation among other Madrasah schools in the City of Padang. They consist of Principals, Teachers, Students, and Educational Personnel. There are three techniques used in data collection, namely observation, interviews and documentation. The stages use the data analysis model Miles and Huberman in Sugiono (2012: 337).

\section{Research Result}

The components of the learning culture identified in MAN 2 Padang consisted of the first, namely the governance of student learning activities. Student learning management is carried out in several forms, such as individual forms, pairs, making small groups, or forming classical groups. Several reasons for consideration were made by MAN 2 Padang when conducting student learning management. Among other types of activities, objectives of activities, student involvement, study time, and the availability of facilities and infrastructure. The most important thing to take into account is the diversity of student characteristics.

The first part is the diversity factor of students and its implications for student learning management, namely, 1). Contents, namely providing opportunities for students in the class to learn subject matter that is not the same in the same or different competencies by utilizing the facilities and infrastructure of MAN 2 Padang school. 2). Students' self-interest and encouragement, give space to students to do creativity that is tailored to their talents, and encouragement in students to continue to hone their intellectual abilities. Because this can be a source of enthusiasm for students to continue to hone their thinking skills 3 ). The learning process is carried out by students, namely to provide a place for students to learn independently based on the processes and stages of learning that each student has. Something that is diverse in terms of (demands) or the contents of the subject matter given, then the learning process that has been carried out in the classroom (Daryanto, 2015: 56).

The significance of the learning culture of the students of MAN 2 Padang above is a reflection of the daily learning activities at the school. MAN 2 Padang is one of the favorite madrasah schools currently in demand. It is inseparable from an activity and learning process that has become a learning culture every day. One example is they make their own study group, which discusses the tasks given by the teacher. In addition, they also memorized the Koran and hadith studies together and in groups. With such a learning culture, it has automatically become a habit that is inherent in each student at MAN 2 Padang.

Secondly, the atmosphere of learning is conducive. The learning system environment includes various things that can facilitate the teaching and learning process in the classroom such as: competence and creativity of the teacher in developing learning materials, the use of varied learning methods and strategies, time management in the teaching learning process and the use of media and learning resources that are suitable for learning and determination of evaluations to measure student learning outcomes. What becomes a measure in creating a 
comfortable learning atmosphere for students is to create a learning atmosphere 1). Relax but still serious, 2). There is active communication between teacher and student, 3). Educate, and 4). Give reinforcement to students. When the teaching and learning process takes place, the teacher is required to create his teaching style. At MAN 2 Padang when learning takes place during the day after the midnight prayer break, most of the students have decreased their learning motivation, the thing that the teacher does at that time is to make students not sleepy and focus back on learning.

The things teachers do to make students focus include: making the classroom atmosphere fun and exciting with the material that has been created by the teacher. From the field findings it is known that "for teachers teaching at noon is a challenge in itself, where teachers are faced with the condition of students who are" less enthusiastic "and in that class the teacher makes a drama in sociology subjects so as to arouse the passion of students in class . For more details, to be easily understood, the following is a picture of "learning culture in MAN 2 Padang".

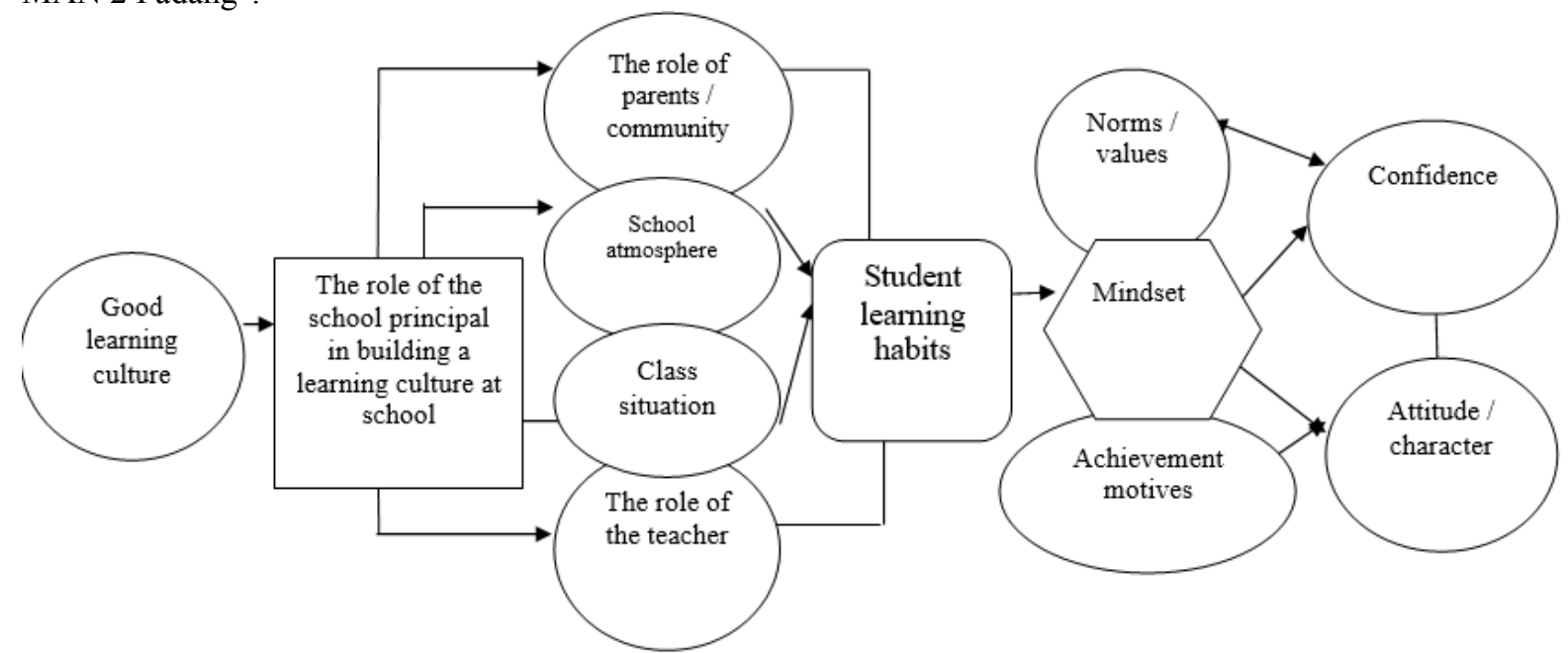

Figure 1.Culture of learning at MAN 2 Padang.

Source: Field Observation

Third, the benefits of learning and school culture in Padang's MAN 2 are improving good behavior according to the mission and vision of the Padang 2 MAN 2 school as a madrasah school, and to inform all school members about whatever behavior should be carried out in the MAN 2 Padang school environment which is done to shape their character and personality within the school environment in accordance with the values, norms and conditions of the school in MAN 2 Padang in the form of surrounding areas or previously implemented culture. One form of condition and culture in MAN 2 Padang has a distinctive characteristic, not not found part of the characteristics contained in the vision or mission of MAN 2 Padang. Therefore a habit created in the MAN 2 Padang area is a characteristic of the madrasa school that has been formed nicely, and carried out, consistently by all school people in MAN 2 Padang.

More and more school people know the core values, and accept the ideas and rules that are in school based on their goals, and are monitored by core values and the old study rules are implemented, therefore the better the behavior they cause. Because all the school people in MAN 2 Padang have a variety of experiences received together, therefore they can make the same goal. This is because the value system of the existing school culture must be well implemented and used as a guide in carrying out activities in school, and has a dynamic nature. To be able to create good school quality and have religious values and be carried out with ownership and trust with MAN 2 Padang, and a sense of belonging, besides participation in carrying out existing rules or core values and making supervision of the behavior of individual school students individually and all school citizens who have a goal in creating and creating a sense of family. This is in accordance with the vision and mission of MAN 2 Padang namely "becoming a superior madrasah and morality" as well as its mission in numbers three and four, namely "the realization of disciplines that are conducive and persuasive madrasah and the realization of environmentally sound madrasah".

With these conditions and coupled with a large contribution to the expectations and ideals of individuals and groups as a manifestation and expectation of the school contained in the vision, mission, goals and objectives of the school supported by a school climate that supports these contributions. The benefits of developing a strong, intimate, conducive and responsible culture and school climate in MAN Padang are: 1) guaranteeing good quality work,) opening up all communication networks of all types and levels of both vertical and horizontal communication, 3) more open and transparent, 4) creating togetherness and a high sense of belonging, 5) increasing solidarity and sense of kinship, 6) if finding a situation will soon be corrected, and 7) can adapt well to the development of science and technology. 
The findings in MAN 2 Padang, factors that influence student learning outcomes include:

1. Family Conditions.

Family conditions and environment greatly affect the success of students in learning at school. For example the economic situation of the family, parental motivation, and parents' views about education. In MAN 2 Padang, from various diverse family backgrounds, but most students who go to MAN 2 Padang come from middle to upper economic circles, this can be seen from the facilities provided to students such as laptops, android phones and private vehicles that can provide motivation and enthusiasm for student learning.

2. Psychological conditions

Based on findings in the field that the psychological condition of each student also determines the success of students in school. It can be followed from motivation to follow the learning process in the classroom, attention and relations with other students. As an example, many students take extracurricular activities both in terms of academics and non-academics, by taking extracurricular activities there are not a few students of MAN 2 Padang who excel, among others students who participate in Porprov, Kejurda and provincial level Olympics and even up to national level . The athletes from MAN 2 Padang are athletes from the Taekwondo branch and 1st place winner Juz Amma in Padang City.

3. School Environment

The condition of a healthy and comfortable school environment in schools also contributes a variety of positive and very significant inputs to student learning activities that have been carried out at school. MAN 2 Padang also shapes the character of students also from a conducive school environment, such as discipline, respect for others. Thus all school members and citizens in MAN 2 Padang perform their respective duties and roles optimally. In addition, the facilities and infrastructure in MAN 2 Padang are very complete to support the learning process in the classroom and other school activities such as existing projector screens in each class, wifi internet networks, sports field facilities, music studios, libraries with complete books .

\section{Conclusion}

The three main findings revealed in study culture studies at madrasah schools in MAN 2 Kota Padang. There are also the following findings, first the management of student learning activities are grouped into various ways, namely individual forms, in pairs, small groups, or classics. Secondly, the atmosphere of learning is conducive. One of the goals in creating a comfortable learning atmosphere is the creation of a learning atmosphere 1). Relax but still serious, 2). there is active communication between teachers and students), 3). Educate, and the last 4). Provide reinforcement to students. Third, the benefits of learning and school culture in MAN 2 Padang, namely growing behavior in accordance with the school's vision and besides that it also informs all citizens of MAN 2 about the conduct that must be implemented in the MAN 2 Padang school environment in order to shape their personalities in the environment school. In addition, there were also factors that influenced student learning outcomes in MAN 2 Padang, namely: 1) Family Conditions, 2) Psychological Conditions, and 3) School Environment.

\section{References}

Agustin, Mubiar. 2011. Pemasalahan Belajar dan Inovasi Pembelajaran.Bandung: Refika Aditama.

Aunurrahman.2011. Belajar dan Pembelajaran. Bandung: Alfabeta

Budiningsih, Asri. 2005. Belajar dan Pembelajaran. Jakarta: Rineka Cipta.

Dalyono. 2001. Psikologi Pendidikan. Jakarta: Rineka Cipta.

Daryanto. 2015. Pengelolaan Budaya dan Iklim Sekolah. Yogyakarta: Gava Media.

Koentjaraningrat. 1990. Bunga Rampai: Kebudayaan Mentalitas dan Pembangunan. Jakarta: PT Gramedia Pustaka Utama.

Rusman. 2017. Belajar dan Pembelajaran. Jakarta: Kencana Prenada Media Group

Slameto. 2003. Belajar dan Faktor-faktor yang Mempengaruhinya. Jakarta: Rineka Cipta.

Sugiyono. 2012. Memahami Penelitian Kualitatif. Bandung: Alfabeta.

Ambiyar dan Nugraha, Hafiz. 2018. Pengaruh Budaya Belajar Terhadap Hasil BelajarnKeterampilan Komputer dan Pengelolaan Informasi Siswa Sekolah Menengah Kejuruan Muhammadiyah 1 Padang. Jurnal Inovasi, Vokasional dan Teknologi Volume 18 No 2 Hlm 49-54.

Arif, Saiful.2011. Budaya Belajar Siswa Pada Sekolah Unggul di SMA Negeri 1 Pamekasan.Jurnal Nuansa Volume 8 No 2 Hlm 183-202.

Christiani, Paulina. 2016. Pengaruh Budaya Sekolah dan Dukungan Orang Tua Terhadap Prestasi Belajar Mata pelajaran IPS Siswa Kelas VII di SMP Negeri 2 Kota Probolinggo.Jurnal JPPI Volume 10 No 1 Hlm 76-89.

Husain, Balqis. 2016. Penggunaan Media Audio Visual Berbasis Kearifan Budaya Lokal Pada Pembelajaran 
Bahasa Inggris Untuk Menanamkan Sikap Nasionalisme.Jurnal Pendidikan Dodoto Volume 12 No 12 Hlm 46-54.

Jabar, AS, Cepi. 2017. Komponen Budaya Sekolah Unggul. Jurnal Kependidikan Volume 1 No 2 Hlm 277-290. Rusnaini dkk.2017. Implementasi BudayanSekolah 7S Dalam Pembentukan Karakter Taat Aturan dan Peduli Lingkungan Peserta Didik.Jurnal PKn Progresif Volume 12 No 1 Hlm 466-481.

Sofli dan Sudrajat, Ajat.Peningkatan Karakter Siswa Melalui Pembelajaran IPS Terpadu Model Nested Di SMP Negeri 3 BangunTapan Bantul. Jurnal Harmoni Sosial Volume 1 No.1 Hlm. 83-94 